\title{
Pengukuran Penerimaan Mobile Internet dengan Path Analysis di Kalangan Mahasiswa Politeknik Negeri Sriwijaya
}

\author{
Irma Salamah ${ }^{1 *}$, RD. Kusumanto ${ }^{1}$ \\ Jurusan Teknik Elektro Politeknik Negeri Sriwijaya Palembang \\ *irma.salamah@yahoo.com
}

\begin{abstract}
Abstrak-Mobile internet ialah teknologi telekomunikasi yang memiliki keunggulan mudah dibawa ke mana-mana karena ukurannya yang kurang lebih sebesar genggaman tangan. Variasi teknologi mobile berkembang karena mengikuti perkembangan zaman, dan menyesuaikan dengan minat dan kebutuhan konsumen. Tuntutan kebutuhan komunikasi, bisnis, informasi, hiburan, sosial-media, dan juga pendidikan yang menggunakan jaringan internet menjadikan kehidupan mahasiswa benar-benar lekat dengan internet. Penelitian ini bertujuan untuk menyelidiki bagaimana pengaruh persepsi kemanfaatan (perceived usefulness), persepsi kualitas (perceived quality), dan persepsi kesenangan (perceived enjoyment) terhadap minat untuk menggunakan (intention to use) internet mobile di kalangan mahasiswa Politeknik Sriwijaya (Polsri). Penelitian dilakukan sekitar 4 bulan dengan sampel 145 mahasiswa. Pengujian dilakukan dengan menggunakan path analysis. Metode analisis ini dipilih karena yang ingin dikethaui adalah seberapa besar pengaruh langsung variabel independen terhadap variabel dependen. Hasil pengujian menunjukkan persepsi kemanfaatan mempunyai pengaruh langsung sebesar 0,383, persepsi kualitas mempunyai pengaruh langsung sebesar 0,271, dan persepsi kesenganan mempunyai pengaruh langsung sebesar 0,245 terhadap minat menggunakan internet mobile pada mahasiswa Polsri. Adanya pengaruh dari ketiga variabel didasarkan pada survei kuesioner, yaitu dukungan dari pihak kampus yang menyediakan bandwidth yang besar membuat mahasiswa memanfaatkan jaringan internet sebagai sumber belajar yang membantu mempermudah dan mempercepat penyelesaian tugas perkuliahan, termasuk tugas akhir. Selain dukungan yang diberikan oleh pihak kampus, kualitas layanan yang diberikan oleh provider telekomunikasi cukup tinggi seperti kecepatan akses dan jangkauan yang luas. Selain memanfaatkan mobile internet dalam proses pembelajaran, mahasiswa juga memanfaatkannya sebagai media hiburan seperti bermain game secara online.
\end{abstract}

Kata Kunci: mobile internet, path analysis, persepsi kemanfaatan, persepsi kualitas, persepsi kesenangan

\section{Pendahuluan}

Perkembangan teknologi informasi kini sudah semakin pesat, di mana manusia sebagai penggunanya tidak luput dari perubahan pola kehidupan akibat perkembangan teknologi. Sejalan dengan tuntutan perkembangan perekonomian nasional, perkembangan teknologi dan sisi lain dalam kehidupan masyarakat serta pengaruh arus globalisasi dunia, pada tahun 2009 terjadi perubahan pola penggunaan internet yang dahulunya banyak yang menggunakan internet di warnet (warung internet) menjadi via mobile-phone. Salah satu fakta menarik yang ditemukan pada penelitian yang dilakukan oleh sebuah agensi survei internasional tentang perkembangan teknologi di Indonesia menunjukkan bahwa 61\% dari total pengguna internet tersebut online melalui perangkat mobile [1]. Jumlah pengguna internet di Indonesia terus bertumbuh secara signifikan dalam beberapa tahun belakangan. Hal ini dapat kita lihat dari data Asosiasi Penyedia Jasa Internet Indonesia (APJII) pada 2016. Tercatat ada 132,7 juta pengguna internet, meningkat 50,3 persen dari 2014. Dalam hal kecepatan koneksi internet, Indonesia pun mulai mengejar negara-negara lain. Berdasarkan laporan kuartal III 2016 dari Akamai, rata-rata kecepatan koneksi di Indonesia adalah 6,4 Mbps, lebih cepat dari Tiongkok yang hanya 5,7 Mbps dan India di 4,1 Mbps [2]. Tuntutan kebutuhan komunikasi, bisnis, informasi, hiburan, sosial-media, dan juga pendidikan yang menggunakan jaringan internet menjadikan kehidupan mahasiswa benar-benar lekat dengan internet. Berbagai perkembangan terbaru ini telah menciptakan sebuah pengalaman mobile internet terkini bagi para pengguna, salah satu pengguna mobile internet adalah mahasiswa. Untuk pelajar atau pun mahasiswa, internet digunakan sebagai sarana yang membantu dalam proses belajar dan sebagai sarana memperoleh data dan informasi. Tetapi banyak juga pelajar dan mahasiswa yang menggunakan internet tidak hanya sebatas media komunikasi saja contohnya yahoo, facebook, twitter, dan lain-lain.

Penelitian ini menguji bagian dari Technology Acceptance Model (TAM) dengan menambahkan variabel perceived enjoyment dan perceived quality untuk menganalisis berbagai faktor yang mempengaruhi penerimaan mahasiswa Politeknik Negeri Sriwijaya terhadap mobile internet. Variabel perceived enjoyment pada penelitian mobile internet pernah dilakukan oleh [3]. Sedangkan variabel perceived quality merupakan variabel dari peneliti sendiri dikarenakan saat ini banyak provider yang menyediakan layanan internet, sehingga pemilihan kualitas dari layanan menjadi penting. TAM merupakan suatu model yang secara luas 
menunjukkan faktor-faktor penentu secara umum dari penerimaan teknologi informasi individual, karenanya dapat digunakan dan telah diterapkan untuk menjelaskan dan memprediksi secara luas perilaku-perilaku pengguna terhadap teknologi [4]. Penambahan variabel perceived enjoyment dan perceived quality ini dengan mempertimbangkan aspek sasaran dari penelitian dan konteks pengguna yang dalam penelitian ini adalah mahasiswa.

Penelitian mengenai penerimaan dan pemanfaatan mobile internet telah dilakukan dengan mengangkat tema yang bervariasi, di antaranya penerimaan mobile TV pada layanan 3G di Indonesia [5]. Hasilnya menunjukkan bahwa konstruksi seperti normative pressure, price level, perceived availability, dan perceived quality merupakan determinan yang kuat dalam memprediksi niat perilaku untuk menggunakan layanan mobile TV 3 G di Indonesia. Penelitian penerimaan mobile internet wi-Bro di Korea telah dilakukan dan menemukan bahwa perceived quality dan perceived availability berpengaruh signifikan terhadap penerimaan mobile internet wi-Bro [6]. Penelitian tingkat penerimaan layanan mobile broadband wireless access di kota Yogyakarta telah pula dilakukan [7]. Hasil penelitian menunjukkan bahwa minat penggunaan dipengaruhi secara signifikan oleh sikap penggunaan layanan. Sedangkan sikap penggunaan layanan berkorelasi positif terhadap perceived usefulness dan perceived enjoyment. Selain itu telah dilakukan penelitian penerimaan mobile internet pada masyarakat pedesaan di Indonesia [8] dan di negara lain di Jerman [9]. Hasil penelitian menunjukkan inovasi, kontak sosial, dan kepercayaan terhadap teknologi menjadi faktor dalam memilih layanan mobile internet. Penelitian mengenai faktor-faktor pemanfaatan internet pada mahasiswa UII Yogyakarta dilakukan oleh [10]. Hasil penelitiannya menunjukkan hiburan, informasi berita, akses, referensi jurnal, akses referensi nonjurnal, komunikasi, e-commerce, pencarian beasiswa, dan pencarian lowongan pekerjaan merupakan faktor-faktor pendorong mahasiswa UII dalam memanfaatkan internet. Penelitian penggunaan internet di kalangan mahasiswa juga dilakukan oleh [11], dan [12], [11] melakukan penelitian mengenai perilaku penggunaan internet di kalangan mahasiswa Fisip Unair dan Fisip UPN. Hasil penelitiannya menunjukkan interaksi sosial dan kepentingan informasi menjadi faktor utama penggunaan internet pada mahasiswa Fisip Unair dan Fisip UPN. Penerimaan mobile internet di kalangan mahasiswa di Bandung dilakukan oleh [12] dengan menggunakan model UTAUT. Hasil penelitian menunjukkan performance expectancy, social influence, faciliating condition, dan perceived flexibility berpengaruh terhadap minat perilaku mahasiswa untuk menggunakan mobile internet. Selain penelitian tentang penerimaan internet, didapati pula banyak penelitian yang memanfaatkan smartphone semisal penelitian oleh [13].

Mobile internet merupakan salah satu perkembangan teknologi informasi. Semakin banyak penduduk Indonesia menggunakan internet. Indonesia Internet Survey 2013 yang dibesut oleh Merketeers bersama MarkPlus Insight menyimpulkan pengguna internet mencapai 74 juta orang atau 28 persen populasi Indonesia. Di tahun 2015 nanti, jumlah pengguna internet diperkirakan melewati 100 juta orang [14]. Besarnya minat masyarakat terhadap adopsi mobile internet tersebut menjadi latar belakang penulis ingin meneliti bagaimana model penerimaan pengguna terhadap mobile internet di kalangan mahasiswa khususnya mahasiswa Politeknik Negeri Sriwijaya (Polsri).

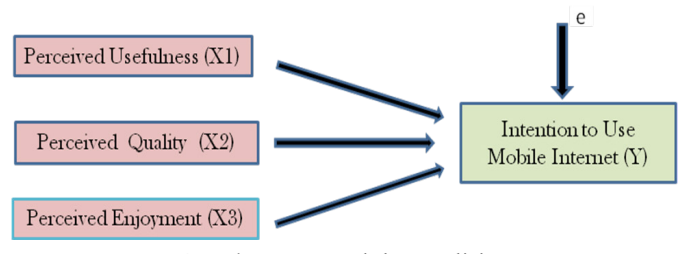

Gambar 1. Model penelitian

\section{Metode}

\section{a. Populasi dan Sampel}

Penelitian dilakukan di Politeknik Negeri Sriwijaya. Penelitian direncanakan selama 5 bulan. Populasi dalam penelitian ini adalah mahasiswa Politeknik Negeri Sriwijaya yang berjumlah 1237. Pengambilan sampel dilakukan dengan teknik convenience sampling. Definisi convenience sampling menurut [15] adalah Convenience sampling refers to the collection the information from members of population who are conveniently available to provide it. Menurut [16] Convenience Sampling cara mengumpulkan informasi dari elemenelemen populasi yang tersedia dengan tidak perlu susah payah. Sebagai contoh, penelitian yang menggunakan teman-teman sekampus, tetangga, saudara-daudara sendiri sebagai responden. Berdasarkan rumus Slovin [15] jumlah sampel yang diambil sebanyak 302. Dari 302 kuesioner yang disebarkan, kuesioner yang kembali hanya 145 kuesioner. Sehingga sampel yang diambil pada penelitian ini berjumlah 145 mahasiswa yang menggunakan mobile internet.

\section{b. Skala Pengukuran Kuesioner}

Kuesioner dalam penelitian ini menggunakan skala likert 5 poin. Skala likert adalah skala yang menunjukkan seberapa kuat tingkat setuju atau tidak setuju terhadap suatu pernyataan [17]. Alasan peneliti menggunakan skala likert adalah untuk memudahkan responden dalam menjawab kuisioner apakah setuju atau tidak setuju, mudah digunakan dan mudah dipahami oleh responden, lebih menarik dan mudah diisi oleh responden.

\section{c. Model Penelitian}

Model penelitian berdasarkan pada model TAM (technology acceptance model) yang disesuaikan dengan fokus penelitian terhadap penerimaan mobile inernet. Model penelitian TAM berfokus pada variabel eksternal perceived usefulness dan perceived ease of use dalam mengkonfirmasi sikap dan minat penggunaan sistem sesungguhnya. Berdasarkan penelitian [6] dan [5] variabel eksternal TAM dapat dikembangkan dengan menambah variabel perceived quality dan perceived enjoyment. Minat untuk menggunakan mobile internet pada penelitian ini sendiri dipengaruhi oleh persepsi kegunaan (perceived usefulness), persepsi kualitas (perceived quality), persepsi kesenangan (perceived enjoyment). Dengan demikian variabel independen dalam penelitian ini adalah persepsi kegunaan (perceived usefulness), persepsi kualitas (perceived quality), persepsi kesenangan (perceived enjoyment), dan variabel dependennya adalah intention to use mbile internet. Modifikasi model TAM dapat dilihat pada gambar 1 berikut ini:

[18] mendefinisikan PU (Perceived usefulness) atau persepsi kegunaan sebagai sejauh mana seseorang meyakini bahwa penggunaan sebuah sistem tertentu akan memberikan kemanfaatan bagi kinerjanya. Dari definisi 
tersebut diketahui jika seseorang merasa percaya bahwa sistem berguna maka dia akan menggunakannya. Sebaliknya jika seseorang merasa percaya bahwa sistem informasi kurang berguna maka dia tidak akan menggunakannya. Dengan demikian PU akan berpengaruh pada sikap pengguna. Selain itu sikap pengguna terhadap suatu sistem juga dapat berpengaruh terhadap niat berperilaku. Hipotesis yang dibangun adalah:

H1: perceived usefulness (PU) berpengaruh terhadap intention to use mobile internet

Kualitas informasi dan layanan menjadi bagian determinan yang menunjukkan sistem atau teknologi tersebut memberi nilai kegunaan dan mudah digunakan [5]. Perceived quality (PQ) didefinisikan sebagai keyakinan atas kepuasan yang dirasakan pengguna terhadap konten dan layanan yang diberikan. Kualitas yang dimaksud di antaranya adalah pelayanan customer service, kualitas video baik, komunikasi suara waktu nyata (real time voice), minim terjadi delay, jitter, dan paket data hilang. Maka dimensi terkait PQ di antaranya adalah kecepatan akses, kualitas konten, dan keandalan. Hipotesis yang dibangun adalah:

H2: perceived quality (PQ) berpengaruh terhadap intention to use mobile internet

Menurut [19] perceived enjoyment adalah the extent to which the activity of using the system is perceived to be enjoyable in it's own right, apart from any performance consequences that may be anticipated. Perceived enjoyment adalah variabel yang memprediksikan tingkat kenyamanan yang dirasakan oleh user selama menggunakan sistem teknologi informasi dalam bekerja [20]. Jika pengguna dapat mengalami kesenangan melalui adopsi teknologi baru, sikap terhadap adopsi teknologi baru tersebut akan positif. Seseorang akan lebih termotivasi untuk melakukan atau mengulang aktivitas yang menyenangkan dibandingkan dengan aktivitas yang sama yang tidak menyenangkan. Hipotesis yang dibangun adalah:

H3: perceived enjoyment (PE) berpengaruh terhadap intention to use mobile internet.

\section{d. Teknik pengumpulan data}

1. Studi Lapangan (Field Research): penulis langsung ke lapangan guna mengetahui permasalahan yang terjadi sekaligus untuk memperoleh data primer yang dibutuhkan yaitu dengan memberikan angket kuesioner kepada pengguna lavanan mobile internet.

2. Studi Kepustakaan (Library Research): mengumpulkan data dengan cara membaca, mempelajari, dan menganalisis buku-buku teknologi informasi yang ada hubungannya dengan masalah yang diteliti.

\section{e. Pengujian Kualitas Data}

Pengukuran variabel dalam penelitian ini dilakukan dengan tujuan agar hipotesis yang diajukan dapat diuji dan pertanyaan penelitian dapat dijawab. Dua kriteria utama untuk menguji seberapa baik instrumen pengukuran yang digunakan yaitu dengan uji validitas dan uji reliabilitas. Validitas adalah ketepatan atau kecermatan suatu instrumen dalam mengukur apa yang ingin diukur. Pada program SPSS teknik pengujian yang sering digunakan para peneliti untuk uji validitas adalah Corrected ItemTotal Correlation. Pengujian validitas juga dilakukan untuk setiap butir pertanyaan yang digunakan dalam variabel. Suatu instrumen dikatakan valid jika nilai corrected item total correlation $>\mathrm{r}$ tabel [7]. Sedangkan uji reliabilitas hanya dapat dillakukan setelah suatu instrumen dipastikan validitasnya. Uji Reliabilitas item adalah uji statistik yang digunakan guna menentukan reliabilitas serangkaian item pertanyaan dalam keandalannya mengukur suatu variabel. Pada program SPSS, uji reliabilitas dilakukan dengan membandingkan nilai koefisien $A$ lpha atau Alpha Cronbach dengan ketentuan nilai $A l p h a$ Cronbach minimal 0,6. Nilai suatu instrumen dikatakan reliable jika nilai cronbach alpha $>0,6[5]$.

\section{f. Pengujian Hipotesis}

Regresi dalam pengertian modern menurut [21] ialah sebagai kajian terhadap ketergantungan satu variabel, yaitu variabel tergantung terhadap satu atau lebih variabel lainnya atau yang disebut sebagai variable-variabel eksplanatori dengan tujuan untuk membuat estimasi dan/atau memprediksi rata-rata populasi atau nilai ratarata variabel tergantung dalam kaitannya dengan nilainilai yang sudah diketahui dari variabel ekslanatorinya. .Pada perkembangan berikutnya, para ahli statistik menambahkan isitilah regresi berganda (multiple regression) untuk menggambarkan proses di mana beberapa variabel digunakan untuk memprediksi satu variabel lainnya. Sebelum dianalisis data tersebut harus diuji apakah melanggar asumsi dasar yang telah ditentukan. Sebelum melakukan regresi harus dilakukan uji asumsi klasik. Uji asumsi klasik terdiri dari uji multikolinearitas, uji normalitas, dan uji heterokedastisitas. Uji normalitas untuk melihat apakah data terdistribusi normal (dengan grafik normal distribution), uji multikolinieritas untuk mengetahui ada atau tidaknya hubungan linier antar variable independen dalam model regresi (dengan nilai VIF $<10$ ), dan uji heterokedastisitas untuk melihat apakah data menyebar secara acak atau tidak (dengan grafik scatter plot).

Pada dasarnya analisis jalur (path analysis) merupakan pengembangan dari analisis korelasi, yang dibangun dari diagram jalur yang dihipotesiskan oleh peneliti dalam menjelaskan mekanisme hubungan kausal antar variabel dengan cara menguraikan koefisien korelasi menjadi pengaruh langsung dan tidak langsung. Selain itu analisis jalur dapat dikatakan sebagai analisis regresi linier dengan variabel-variabel yang dibakukan. Oleh karena itu, koefisien jalur pada dasarnya merupakan koefisien beta atau regresi baku.

Pemilihan analisis jalur pada penelitian ini dikarenakan peneliti ingin mengetahui seberapa besar pengaruh langsung variabel independen terhadap variabel dependen. Besarnya pengaruh tersebut dapat dilihat dari koefisien jalur. 


\section{Hasil dan Diskusi}

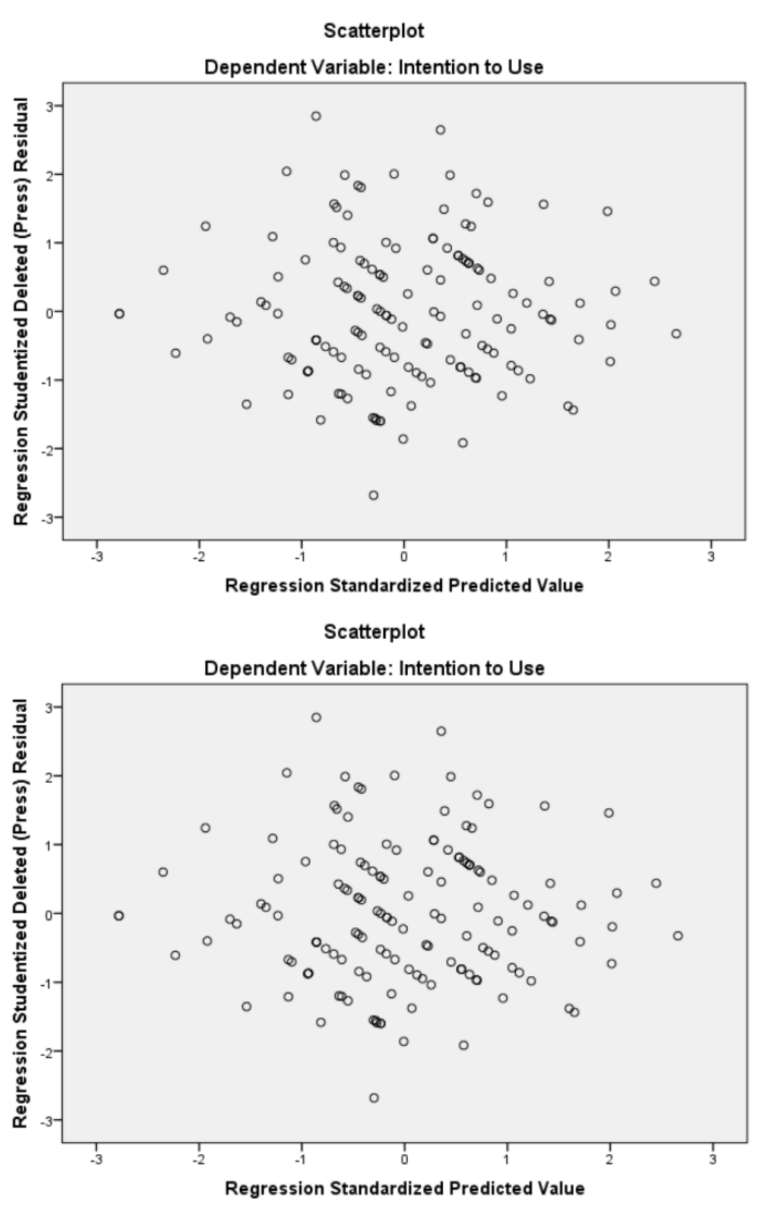

Gambar 2. Hasil uji normalitas dan heterokedastisitas

Tabel 1. Hasil Uji Validitas X1, X2, X3, dan Y

\begin{tabular}{llllllll}
\hline \multicolumn{7}{c}{ CICT } \\
\hline \multicolumn{1}{c}{ X1 } & \multicolumn{2}{c}{ X2 } & \multicolumn{2}{c}{ X3 } & \multicolumn{2}{c}{ Y } \\
\hline X1.1 & 0,497 & X2.2 & 0,506 & X3.1 & 0,720 & Y1.1 & 0,647 \\
X1.2 & 0,609 & X2.2 & 0,509 & X3.2 & 0,745 & Y1.2 & 0,665 \\
X1.3 & 0549 & X2.3 & 0,649 & X3.3 & 0,673 & Y1.3 & 0,659 \\
& & X2.4 & 0,517 & X3.4 & 0,574 & & \\
\hline
\end{tabular}

Tabel 2. Hasil Uji Reliabilitas X1, X2,X3, dan Y

\begin{tabular}{cc}
\hline Variabel & Cronbanch Alpha \\
\hline $\mathrm{X} 1$ & 0,728 \\
$\mathrm{X} 2$ & 0,743 \\
$\mathrm{X} 3$ & 0,842 \\
$\mathrm{X} 4$ & 0,804 \\
\hline
\end{tabular}

Di mana:

r table $=0,162$

$\mathrm{X} 1$ : Perceived Usefulness (persepsi kemanfaatan)

$\mathrm{X} 2$ : Perceived Quality (persepsi kualitas)

$\mathrm{X} 3$ : Perceived Enjoyment (persepsi kesenangan)

$\mathrm{Y}$ : Intention to use mobile internet (minat menggunakan mobile internet)
Tabel 3. Model Summary

\begin{tabular}{ccccc}
\hline & R Square & Beta & Sig & VIF \\
\hline $\mathbf{X} 1$ & & 0,383 & 0,00 & 1,345 \\
$\mathbf{X} 2$ & 0,517 & 0,271 & 0,00 & 1,435 \\
$\mathbf{X} 3$ & & 0,245 & 0,01 & 1,391 \\
\hline
\end{tabular}

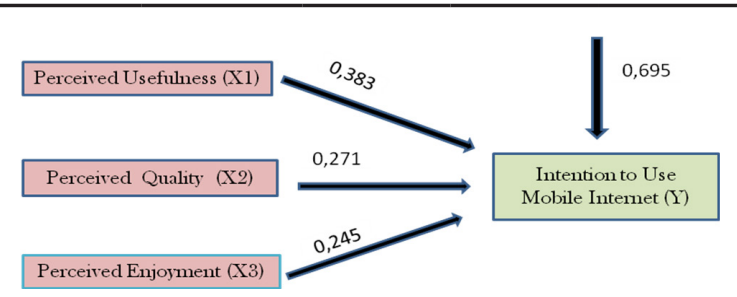

Gambar 3. Model diagram jalur

Dari tabel terlihat hasil uji validitas untuk X1, X2, $\mathrm{X} 3$, dan $\mathrm{Y}$ diperoleh $\mathrm{r}$ hasil (corrected item-total correlation) $>\mathrm{r}$ tabel. Dengan demikian maka variabel perceived usefulness, perceived quality, perceived enjoyment, dan intention to use dinyatakan valid dan layak digunakan untuk penelitian. Hasil uji reliabilitas nilai cronbach alpha X1, X2, X3, X4, dan Y lebih besar dari $r$ tabel (cronbach alpha $>$ r tabel). Dengan demikian maka perceived usefulness, perceived quality, perceived enjoyment, dan intention to use dinyatakan reliabel dan layak digunakan untuk penelitian.

Dari gambar 2 terlihat bahwa data terdistribusi mendekati garis normal dan menyebar secara acak. Sedangkan pada tabel 3 terlihat bahwa nilai VIF untuk persamaan adalah lebih kecil dari 10, sehingga dapat dikatakan bahwa tidak ditemukan adanya masalah multikolinearitas.

Dari tabel 3 nilai $\mathrm{R}$ square 0,517 yang berarti perceived usefulness, perceived quality, dan perceived enjoyment mempengaruhi intention to use mobile internet sebesar 51,7\%. Sedangkan sisanya sebesar $48,3 \%$ dipengaruhi oleh faktorfaktor lain yang tidak dimasukkan dalam penelitian. Nilai dapat dihitung $e=\sqrt{1}-0,517=0,695$.

Berdasarkan output regresi pada bagian tabel 3, terlihat nilai signifikansi perceived usefulness lebih kecil dari 0,05 $($ Sig $<0,05)$ dengan nilai koefisien jalur sebesar 0,383. Nilai signifikansi perceived quality lebih kecil dari 0,05 $(\mathrm{Sig}<0,05)$ dengan nilai koefisien jalur sebesar 0,271. Nilai signifikansi perceived enjoyment lebih kecil dari 0,05 (Sig<0,05) dengan nilai koefisien jalur sebesar 0,245 . Hal ini berarti perceived usefulness, perceived quality, dan perceived enjoyment berpengaruh secara langsung terhadap intention to use mobile internet. Dengan demikian $\mathrm{H} 1, \mathrm{H} 2$, dan $\mathrm{H} 3$ diterima.

Persamaan model struktural: $\mathrm{Y}=0,383 \mathrm{X} 1+0,271 \mathrm{X} 2$ $+0,245 \mathrm{X} 3+0,695$. Model diagram jalur seperti gambar 3 .

Dari gambar 3 terlihat perceived usefulness memiliki nilai koefisien jalur paling besar. Hal ini menunjukkan perceived usefulness memiliki pengaruh yang paling kuat terhadap intention to use mobile internet. Kemudian diikuti oleh perceived quality dan perceived enjoyment.

\section{Kesimpulan}

Berdasarkan bukti-bukti empiris hasil survei yang diperoleh maka disimpulkan bahwa persepsi kegunaan (perceived usefulness), persepsi kualitas (perceived quality), dan persepsi kesenangan (perceived enjoyment) berpengaruh secara langsung terhadap keinginan menggunakan (intention to 
use) dari teknologi mobile internet. Perceived usefulness menjadi faktor terkuat mahasiswa Polsri untuk menggunakan mobile internet. Hal ini dikarenakan mahasiswa Polsri lebih banyak menggunakan mobile internet untuk mengakses berbagai informasi dan ilmu pengetahuan sesuai kebutuhan yang relevan dengan subjek mata kuliah. Sehingga pemanfaatan jaringan internet sebagai sumber belajar akan membantu mempermudah dan mempercepat penyelesaian tugas perkuliahan, termasuk penyelesaian tugas akhir mahasiswa. Pada penelitian ini ditambahkan variabel perceived quality sebagai variabel yang belum pernah diteliti pada penelitian sebelumnya mengenai mobile internet. Penambahan variabel perceived quality dikarenakan saat ini banyak providerprovider yang menyediakan layanan internet yang tentunya konsumen akan memilih provider dengan kualitas layanan yang bagus. Politeknik Negeri Sriwijaya telah menyediakan bandwidth yang cukup besar yang menjadikan kualitas layanan internet Politeknik Negeri Sriwijaya sangat mendukung untuk proses pembelajaran. Selain dukungan yang diberikan oleh pihak kampus, kualitas layanan yang diberikan oleh provider-provider telekomunikasi pun sudah semakin meningkat seperti kecepatan akses dan jangkauan yang semakin luas. Oleh karena itu perceived quality menjadi faktor terkuat kedua yang mempengaruhi minat penggunaan mobile internet mahasiswa Polsri. Perceived enjoyment menjadi faktor terakhir yang mempengaruhi minat penggunaan mahasiswa Polsri dalam menggunakan mobile internet. Hal ini dikarenakan mahasiswa Polsri lebih mengutamakan penggunaan mobile internet dalam mendukung proses pembelajaran bukan sebagai media hiburan.

\section{Daftar Pustaka}

[1] P. Editor, "Perkembangan Teknologi di Indonesia: Internet \& Mobile (part-1)," Plimbi. com, 2012.

[2] S. Kamath, "4 Prediksi Tren Mobile Internet di Indonesia Tahun 2017,” Liputan 6.com, 2017. .

[3] R. Roostika, "Mobile Internet Acceptance Among University Students: A value-based adoption model," Int. J. Res. Manag. Technol., vol. 2, no. 1, pp. 21-28, 2012.

[4] F. D. Davis, "Perceived Usefulness, Perceived Ease of Use, and User Acceptance," MIS Q., vol. 13, no. 3, pp. 319-339, 1989.

[5] A. Qiantori, A. B. Sutiono, H. Suwa, and T. Ohta, "3G mobile TV Acceptance in Indonesia," Proc. - 6th Int. Conf. Wirel. Mob. Commun. ICWMC 2010, pp. 526-531, 2010.

[6] D. H. Shin, "User Acceptance of Mobile Internet: Implication for Convergence Technologies," Interact. Comput., vol. 19, no. 4, pp. 472-483, 2007.

[7] Inasari Widiyastuti, "Analisis Penerimaan Layanan Mobile Broadband Wireless Access di Kota Yogyakarta," vol. 10, no. 1, pp. 1-12, 2012.

[8] C. Agustina, P. Studi, and M. Informatika,
"Evaluasi Penerimaan Penggunaan Mobile Internet Pada Masyarakat Pedesaan," vol. 2, no. 2, pp. 29-35, 2014.

[9] J. Koenigstorfer and A. Groeppel-Klein, "Consumer Acceptance of the Mobile Internet," Mark. Lett., vol. 23, no. 4, pp. 917928, 2012.

[10] A. Zaim, Nugroho, "Analisis Faktor-Faktor Pemanfaatan Internet Oleh Mahasiswa di UII Yogyakarta,” pp. 6-8, 2015.

[11] I. Novianto, "Perilaku Penggunaan Internet di Kalangan Mahasiswa (Studi deskriptif tentang perilaku penggunaan internet di kalangan mahasiswa perguruan tinggi negeri (FISIP UNAIR) dengan perguruan tinggi swasta (FISIP UPN) untuk memenuhi kebutuhan informasinya)," Univ. Airlangga, pp. 1-40, 2016.

[12] I. I. Wiratmadja, R. Govindaraju, and N. Athari, "The Development of Mobile Internet Technology Acceptance Model," 2012 IEEE Int. Conf. Manag. Innov. Technol., pp. 384-388, 2012.

[13] D. Pratama, D. A. Hakim, Y. Prasetya, N. R. Febriandika, M. Trijati, and U. Fadlilah, "Rancang Bangun Alat dan Aplikasi untuk Para Penyandang Tunanetra Berbasis Smartphone Android," Khazanah Inform. J. Ilmu Komput. dan Inform., vol. 2, no. 1, pp. 14-19, 2016.

[14] M. Fauziah, "Survei: Pengguna Internet di Indonesia Mencapai 74 Juta Orang," Republika, 2013.

[15] S. Uma. Metodologi Penelitian untuk Bisnis, 4th ed. Jakarta: Salemba Empat, 2006.

[16] Sarwoko. Statistik Inferensi. Yogyakarta: Andi, 2007.

[17] C. J. McDaniel and R. \& Gates, Marketing Research Essentials, 8th ed. New York: John Wiley and Sons., 2013.

[18] F. D. Davis, R. P. Bagozzi, and P. R. Warshaw, "User Acceptance of Computer Technology: A Comparison of Two Theoretical Models," Management Science, vol. 35, no. 8. pp. 982-1003, 1989.

[19] F. D. Davis, R. P. Bagozzi, and P. R. Warshaw, "Extrinsic and Intrinsic Motivation to Use Computers in the Workplace," J. Appl. Soc. Psychol., vol. 22, no. 14, pp. 1111-1132, 1992.

[20] S. S. Al-Gahtani and M. King, "Attitudes, Satisfaction and Usage: Factors Contributing to Each in the Acceptance of Information Technology," Behav. Inf. Technol., vol. 18, no. 4, pp. 277-297, 1999.

[21] D. N. Gujarati and D. C. Porter, Basic Econometrics. McGraw-Hill Irwin, 2009. 